\title{
Dead time: Cinema, Heidegger, and boredom
}

\section{Richard Misek}

\begin{abstract}
This article explores cinematic boredom. It investigates how feature films exemplify prevailing cultural attitudes towards boredom, and suggests that dominant cinema's fear of being 'boring' reflects a cultural refusal to address the implications of time passing. Most feature films kill time. The article analyses how and why they do so, and then explores what happens when a film refuses to kill time. By engaging with temporality, a film may risk being called 'boring' but it may also perform the important cultural role of encouraging us to reflect on the limited time-span of our own lives.
\end{abstract}

Keywords. Boredom; film; time; speed; slowness; death.

This article investigates how films engage with, and exemplify cultural attitudes towards, boredom. When used of a film or other cultural product, the term 'boring' typically implies low artistic quality. But does this negative use of the term perhaps tell us more about capitalist culture's apprehensive attitude towards boredom than about the 'boring' object itself? In this article, I attempt partially to rehabilitate boredom as an integral element of the taking of time to engage with time. In this, I take my lead from a series of lectures by Martin Heidegger entitled The Fundamental Concepts of Metaphysics. One might imagine that a hundred pages on the subject by Heidegger would itself constitute the ne plus ultra of boredom. Instead, I believe that his discussion of boredom as a relation to time provides a useful, and perhaps even interesting, basis for exploring it in relation to the time-based medium of film. I begin by summarising and glossing Heidegger's discussion of boredom, and then feed his ideas into an analysis of how films engage - or fail to engage - with temporality. I focus in particular on two types of film: those that kill time, and those that bore to death. 
How to begin an analysis of boringness and boredom? One might perhaps try first to establish what each is, and how each relates to the other. To this end, Heidegger differentiates three 'aspects' of boringness and boredom: '[1.] that which is boring in its boringness; [2.] becoming bored by this boring thing and being bored with such a thing; [3.] boredom itself' (Heidegger 1995, 83). According to this taxonomy, 'boringness' is a property of an object; it acts on us in the form of the experience of 'becoming bored by' or 'being bored with'; through this experience, the object provokes in us a mood of 'boredom'. In other words, boringness is a primary quality, and is an objective characteristic (Heidegger 1995, 84). Boredom is a secondary quality, like colour, and is subjective (Heidegger 1995, 84). Boringness causes boredom.

Though intuitive, the above taxonomy is rather simplistic. Unsurprisingly, Heidegger immediately problematises it. He asks, for example: 'Are these three pieces which belong together? Or is it merely [1.] and [2.] which belong together? Or are they in general one and the same, in each case seen from a different perspective?' (Heidegger 1995, 83). The answer is that we cannot be sure. As Heidegger notes, distinguishing between boringness and boredom gets us nowhere: 'For as soon as we start with what is boring, we will find ourselves saying: it is whatever bores us and thus causes boredom' (Heidegger 1995, 83). Heidegger then suggests that if it is only possible to apprehend seemingly objective phenomena such as 'boringness' through subjective experience, then we must first consider the subjective experience itself - boredom (Heidegger 1995, 83). Perhaps it is even possible to assert the primacy of boredom over 
boringness by suggesting that 'properties do no accrue to things themselves but are representations, ideas that we as subjects transfer onto objects' (Heidegger 1995, 85). When bored by a film, for example, we may say that the film is boring. Asserting boringness becomes a means of simultaneously concealing and lending weight to our subjective response of boredom. Perhaps the assertion of boringness is little more than a form of self-defence, an assertion that it is not our fault we were bored, but the fault of the work. Perhaps, in short, boringness is a construct. It is certainly true that assertions of objects' boringness are often coded expressions of boredom. But can we go so far as to say that boringness does not exist? Heidegger suggests that we cannot. When we regard an object as boring, there must be something about it that prompts us to experience boredom in relation to that particular object and not another; there must be something of the boring within it (Heidegger 1995, 85). Yet asserting that boredom and boringness are distinct phenomena is also inadequate, as it cannot resolve the contradiction that '[c]haracteristics such as 'boring'... belong to the object and yet are taken form the subject' (Heidegger 1995, 86).

Heidegger instead posits that a boring thing 'does not cause the boredom, yet nor does it receive it merely as something attributed by the subject. In short: boredom ... is a hybrid, partly objective, partly subjective' (Heidegger 1995, 88). This proposition allows Heidegger at last to focus precisely on what he wishes to discover, namely the relation that exists between subject and object when the subject is bored: 'not the interpretation of what is boring as such, but becoming bored by such a thing, being bored with [it]' (Heidegger 1995, 91). For Heidegger, 
'becoming bored by' and 'being bored with' are distinct. The former involves 'being held in limbo', while the latter involves 'being left empty' (Heidegger 1995, 113). 'Becoming bored by' involves an immediate experience of boredom in a specific situation; Heidegger's example is that of waiting for four hours in a rural railway station - as one waits, one becomes bored by the wait (Heidegger 1995, 94). 'Being bored with' describes a form of attunement that is not focused on the present moment, and that involves a degree of detachment from the boring thing. It is typified by being at a dinner party, having a good time, but subsequently feeling that the whole evening was empty and valueless (Heidegger 1995, 109)."i. In this article, I shall focus primarily on the immediate experience of 'becoming bored by something'. The something that I shall focus on is films.

Time must pass for us to become bored by something. (Heidegger 1995, 91). Furthermore, 'becoming bored by' something requires an imposed experience of passing time - if we are not 'firmly stuck with the situation', we cannot become bored by it (Heidegger 1995, 108). A photographic exhibition, for example, is unlikely to bore: if we do not find a photograph interesting, we can just move on. But if we visit the exhibition with someone who spends ten minutes looking at each photograph, we may become bored by the exhibition, as the duration of the visit is not under our control. The duration of our experience of watching a film is, at least in a cinema, also not under our control: if the film is two hours long, the experience lasts two hours - unless we are so bored that we walk out.ii Because it imposes duration, cinema is a privileged site of boredom. By imposing its own temporality onto objects, it can even make possible boredom 
in response to objects that are not ordinarily associated with it. For example, though we are unlikely to become bored by a photograph in a gallery, we may become bored by a shot of a photograph or a still image in a film. A viewer may, for example, feel that the thirteen shots of photographs that constitute Hollis Frampton's Nostalgia (1971), or even the still images that constitute Chris Marker's La Jetée (1962), last too long. I shall explore films that use their duration to cultivate the feeling of time passing in more detail later. First, however, I wish to focus on films that downplay duration and try to make us forget about the passing of time.

\section{Killing time}

Boredom is something that we typically seek to 'escape' (Heidegger 1995, 78). Films provide the 'escapism' through which this can be achieved. They typically focus on fictional lives, allowing us to escape from our own, and fill their duration (and our time) with action: process-based activities, characters pursuing goals,

dramatic confrontations, complex plots, and so on. This is the form of escape that Siegfried Kracauer criticises in his brief but evocative article, Boredom. Kracauer's view of boredom, like Heidegger's, is (perhaps excessively) celebratory. He sees it as pure untapped potential: 'In the evening one saunters through the streets, replete with an unfulfillment from which a fullness could sprout' (Kracauer 1995, 332). However, instead of engaging creatively with our boredom, we are distracted by the sights and sounds of city streets. Prominent 
among these are advertisements, which may in turn lure us into a movie theatre. Once we have settled in front of a cinema screen, we allow a film to pass time for us: 'One forgets oneself in the presence of gawking, and the huge dark hole is animated with the illusion of a life that belongs to no one and exhausts everyone (Kracauer 1995, 332). Cinema fills the 'huge dark hole' of the auditorium and of our lives with the sounds and images of fictional lives, thereby preventing us from finding fulfillment within ourselves, and paradoxically leaving us feeling empty. It also offers another form of escape, namely escape from feeling time passing. Though train stations are indifferent about the effect imposed duration has on us, film-makers are not. Most films provide us with something to do to pass time hence the appeal of watching films on long-haul flights and train journeys. Heidegger notes that in escaping the feeling of time passing, we 'kill time' (Heidegger 1995, 93). We kill time because when we find something to do in order to pass time, time does not pass more quickly, rather it is completely annulled - we do not notice it passing at all (Heidegger 1995, 99). ${ }^{\text {iv }}$

Sergio Leone's Once Upon a Time in the West (1968) offers a range of strategies for killing time. Three killers wait for a train at an isolated train station. Train stations, like films, also impose duration, and so are also privileged sites of boredom. Heidegger's description of 'the tasteless station of some lonely minor railway' is worth citing at length here:

It is four hours until the next train arrives .... We read the timetables or study the table giving the various distances from this station to other places we are not otherwise acquainted with at all. We look at the clock - only a quarter of an hour has gone by. Then we go out onto the local road. We walk up and down, just to have something to do. But it is no use. Then we count the trees along the road, look at our watch again - exactly five minutes since we last looked at it. (Heidegger 1995, 93) 
Everywhere we look in a train station, we see clocks and screens displaying departure times, encouraging us to quantify how much longer we will be held in limbo. But to do so is a mistake, as time slows when we count it down. Though they are surrounded by reminders of time passing, instead of quantifying time, Leone's gunmen find ways to kill it. Each does so in a slightly different way. One feels time passing physically by means of drops of water dripping on his hat, quantifying the duration of his wait like the ticking of a clock quantifies time. He kills time by incorporating the dripping into a fastidious process: he allows water to fill the rim of his hat, carefully raises the hat, and drinks from it without spilling a drop. The second attempts to kill time by snoozing, but a ticking telegraph machine disturbs his nap, so he rips out its wires. Then a buzzing fly lands on his face, so he kills time by setting himself the goal of getting rid of it without moving his hands. This activity does not yield the desired result, so he finds a new form of distraction - he traps the fly in the barrel of his pistol, entertaining himself with the echoing sound of it buzzing around. Perhaps the most interesting response to time passing, however, is that of the third killer, to whom Leone gives the least screen time. The third killer does not kill time through action. He just stands at the side of the track, looking into the distance and waiting. As he does so, the camera remains motionless, and the scene approaches the stillness of a photograph. Accompanying this stillness is the rhythmic creaking of the rotating blades of a windmill on the station platform. The creaking again quantifies time like the ticking of a clock, but the killer remains indifferent and does nothing. 
The opening of Once Upon a Time in the West is a virtuosic evocation of time passing. However, for most of its duration, the sequence kills time with action. The unusual miniature activities of hat water drinking and fly baiting are magnified by Leone's close-ups, and become widescreen spectacle. The stillness of the sequence also serves to build suspense. This is a self-reflexive western, so we know (and Leone knows we know) that there will be a shoot-out when the train finally arrives. Though the killers' progress is temporarily stilled at the station, they are nonetheless on a journey that will end with someone being killed. In the meantime, they pass time in various entertaining ways. But ultimately, by killing time, Leone's killers hasten their own death. When the train finally arrives, they do not have time to kill their intended victim, because he is a faster shot, so they are killed. With hindsight, we see that they have in fact been in limbo, waiting for their own death.

If a film makes us forget about time passing, it provides entertainment. The opening of Once Upon a Time in the West constitutes a brilliant entertainment that simultaneously presents us with the passing of time and provides us with an escape from it. When we watch an entertaining film, the passing of the time of our lives is annulled by the passing of time within the film. Director Andrzej Wajda recounts a conversation on this theme:

Many years ago when I made my film Ashes and Diamonds [1958], a very long two-part work, I was afraid of the public's reaction. I expressed my fear to a Polish writer who said to me, 'What l'd like to see you make is a film so long l'd never have to leave the theater.' (Wajda 1989, 114)

Wajda's friend wanted to see a film that provided him with a permanent escape from the passing time of his life. Kracauer, of course, would regard this escape 
as a bad thing. A constant escape from boredom would bring about a kind of selferadication. In a beautiful conceit, Kracauer does not associate absence with boredom, in the form of absence of activity, fun, and so on; rather, he associates it with activity, in the form of absence from ourselves: 'If one were never bored, one would presumably not really be present at all and would thus be merely one more object of boredom...' (Kracauer 1995, 334). Of course, the option of never being bored is impossible. There is no mode of travel that does not involve waiting, and no film that lasts a lifetime. Wajda's friend sought a film that would offer him a permanent escape from himself. But he could not find one. Instead, he chose the only remaining option: he killed himself.

Wajda's example demonstrates why, in my view, Kracauer goes too far in celebrating boredom. In particular, his suggestion that the best thing to do is 'hang about in the train station or, better yet, stay at home, draw the curtains, and surrender oneself to one's boredom on the sofa' seems altogether too glib (Kracauer 1995, 334). I agree with Kracauer that boredom can be a valuable experience and even a creative force. But it can also be dangerous. Boredom can bring us face-to-face not just with ourselves but with the emptiness of our lives. Boredom foregrounds the passing of time, and reminds us that our waiting will eventually end not with a train arriving but with death. Magnus Aronson notes that to be aware of passing time is to face our mortality and the shortness of the time-span of our lives (2002). When we sit bored at a train station, like the killers in Once Upon a Time in the West, we count down time until we will die. 


\section{'Becoming bored by'}

If a film kills time, then we do not feel bored while watching, though we may still afterwards look back on the experience and be left feeling empty as a result; in this case, we experience the retrospective state of 'being bored with' something. Alternatively, a film may fail to kill time. If this occurs, then we feel time passing and may become bored by it. 'Becoming bored by' a film relates both to its duration and to the time killing options it offers within that duration. Lars Svendsen suggests that it is not the length of the imposed duration that relates to our 'becoming bored by' but the pace at which time passes:

In boredom, time is slow, and because of this slowness we notice that we are not in charge of time, that we are subject to time. We attempt to drive away this power by means of our everyday pastimes ... We seek to be occupied because it liberates us from the emptiness of boredom. When we manage to stay fully occupied, time disappears in favour of whatever fills it.' (Svendsen 2005, 118)

Though Svendsen's summary of the relationship between boredom and slowness is hard to fault, he skips over Heidegger's crucial point that we become bored by something 'not because the progress of time is slow, but because it is too slow' (Heidegger 1995, 97). The italicised 'too' reminds us that 'becoming bored by' is a subject-object relation, and so is also dependent on our expectations. Heidegger elaborates as follows: 'Boredom is only possible at all because each thing, as we say, has its time. If each thing did not have its time, then there would be no boredom' (Heidegger 1995, 105). This is a crucial point. Boredom occurs when there is a mismatch between our time and an object's time. By way of example, Heidegger returns to the train station. His four-hour 
wait involves a mismatch between the 'ideal' time of the train station (that is, the time that he wishes to spend there), which would ideally be not time at all, and the actual time he spends there. Heidegger's analytic framework can also be applied to the 'object' of a film: 'becoming bored by' a film involves a mismatch between the 'ideal' speed at which we want it to move and the actual speed at which it moves. ${ }^{\vee}$ I elaborate this point with some generic examples, as our expectations of a film are dependent on its genre. When we watch a romantic comedy, we may expect the central relationship to develop slowly. When we watch an action film, we may expect a high-speed plot; if instead we get a slowmoving plot, we may become bored.

Boredom occurs when a film is 'too slow'. vi Dominant cinema typically utilises various forms of speed (activity-filled narratives, rapid camera movement, fast cuts, up-tempo soundtracks, and so on) to keep us entertained. ${ }^{\text {vii }}$ Yet fast films can also bore.

An example of a film that tries and, in my view, fails to kill time is I Am Legend (Francis Lawrence, 2007). I Am Legend is a remake of The Omega Man (Boris Sagal, 1972), both of which begin with a day in the life of Robert Neville, possibly the last surviving man on earth. The Omega Man begins with a sequence in which Neville (Charlton Heston) drives through the empty streets of Los Angeles. Like Wajda's friend, he finds escape from his unbearable life through moviegoing. He stops off at a cinema to watch Woodstock (Michael Wadleigh, 1970). As he watches hippies hugging and talking about togetherness, he loses track of time until it is almost sunset. Once the sun goes down, the vampiric members of 
the 'family' will come out of hiding. Realising he is out of time, Neville speeds home. He gets back to face an ambush outside his house, and only narrowly escapes from having to pay for his slowness with his life. Once he is home safe, he returns to his solitary quotidian activities - fixing himself drinks, playing chess with a plaster bust, and picking off an occasional 'family' member with his sniper's rifle. Though The Omega Man is no masterpiece, the opening sequence functions in a similar vein to Once Upon a Time - it signals boredom as a theme, but makes it entertaining. The weight of time presses heavily on Neville, as demonstrated by the fact he knows all the words spoken in Woodstock off by heart. Boredom also partially motivates the film's opening action sequence Neville is ambushed by the 'family' because he has spent too long in the cinema.

I Am Legend also begins with a typical day in the life of Robert Neville (now played by Will Smith, and transplanted to Manhattan). In contrast to his 1970s namesake, however, I Am Legend's Neville is altogether more purposeful. The film begins in medias res, by playing up to generic expectation with a highspeed chase, in which Neville uses a sports car to hunt a herd of deer roaming the empty city streets. In contrast to the narrative flânerie of The Omega Man, I Am Legend literally speeds through its opening sequence. In cutting to the chase, the film chooses not to evoke its main character's boredom and isolation by engaging with how he kills time; rather, the screenwriters themselves kill screen time by providing the kind of kinetic entertainment that customarily begins Hollywood action films. Once Neville returns home, the film continues to downplay the theme of boredom. Instead of indulging in the kinds of eccentric 
and depressive activities that Heston's Neville half-heartedly pursues, Smith's Neville cooks, washes his dog, and puts serious time into his scientific research.

Even though they provide Neville with purposeful activities, the film's screenwriters still seem scared to leave viewers alone with him. Instead of allowing us to look his isolation in the face, they intersperse scenes of his empty life with flashbacks to the night of the disaster that depopulated Manhattan. In the first flashback sequence, Neville informs his wife that the clock is ticking, and the army will be sealing off Manhattan in thirty minutes. In the subsequent, chronologically sequential flashback sequences, Neville and his family race in a car (speed again!) to beat the deadline. The thirty-minute countdown plays out almost in real time, albeit spread across multiple flashback sequences, providing Neville with ample opportunity for profound last moments with his family, heroic self-sacrifice, and high-speed driving. The flashbacks also enable the film's screenwriters to duck the philosophical theme of boredom by implying that Neville's present depression is due to a simple causal factor: the death of his family.

Robert Neville is a perfect embodiment of Kracauer's idea that being alone with oneself is a terrifying but potentially creative state; out of his emptiness, he eventually manages to create a vaccine for the virus that has all but wiped out humanity. There is a provocative theme here waiting to be explored, but I Am Legend avoids the explicit engagement with dead time demonstrated by Once Upon a Time and, to a lesser extent, The Omega Man. It does not repeat the two films' balancing acts between engaging with characters' boredom and causing 
viewers' boredom; rather, it just attempts to kill time. Though the film focuses on a limit-case of boredom, it manifests a fear of boredom. Ironically, by resorting to oft-repeated Hollywood conventions for killing time (for example, legibility, emotional transparency, dramatic 'stakes', violent confrontation), I Am Legend risks doing what it most fears, namely, boring.

\section{Dying of boredom}

Films typically relate to time in one of two ways. The first involves killing time. In this, a film may succeed or fail. If a film succeeds in killing time, we are entertained by it, though afterwards we may be bored with it. Of course, as the restless fly-baiter in Once Upon a Time in the West demonstrates, it is not always easy to kill time. If a film fails to kill time, we feel time passing as we watch it, and may become bored by it. Some films, however, refuse to kill time. Such films are conscientious objectors to the time-killing strategies of dominant cinema, and encourage us instead to feel time passing.

One cinematic means of engaging with the passing of time involves creating the 'complex temporal structures' that characterise the Deleuzian timeimage (Deleuze 1989, xii). Deleuze's 'time-image' hinges on the presence of 'false continuity' editing, which juxtaposes disparate temporalities and creates complex patterns of connection between them, thereby emulating the complexity of our experience of time (Deleuze 1989: 40). The quintessential example of this approach is Resnais's Last Year at Marienbad (1963). An alternative means of 
foregrounding temporality involves allowing screen time to pass without the distraction of goal-oriented activity or stylistic contrivance, simply by lingering on characters who feel time passing. The history of art cinema, in particular, includes numerous culturally disparate examples of films structured around dead time - from Andrei Tarkovsky's Andrei Rublev (1966), via Jim Jarmusch's Stranger than Paradise (1984), to Abbas Kiarostami's The Wind Will Carry Us (1999). These films confront us with the passing of time by emptying the screen and the soundtrack of any content that may prevent the viewer from feeling time passing (for example, dramatic conflict, music, elaborate camera movement and lighting design, etc.). Rather than killing time, such films typically bore to death.

The Wind Will Carry Us (1999) provides a particularly rich example of how a film can use dead time as a structuring principle. It follows the lack of progress of an engineer (Behzad Dourani) hoping to carry out a job in an Iranian village. For unspecified reasons, work cannot commence until an ailing elderly character dies. Unfortunately for the engineer, the elderly character proves to have a stubborn hold on life. Having expected to wait only a day or two, the engineer finds his work indefinitely delayed. Days become weeks, the old woman lives on, and the engineer finds his goal-orientated approach to time folded into the villagers' more relaxed pace. The film uses various techniques typically associated with 'boring' films to heighten the sense of time passing. These include repetition (the main character's daily routine revolves around driving up a hill so he can get phone reception and update his employer about his lack of progress); silence (the film features no scored music); the kinds of long duration 
'sequence shots' famously celebrated by Andé Bazin; and above all a narrative that often provides little to focus on apart from routines that emphasise the passing of time (milking a cow, drinking tea, driving in circles). ${ }^{\text {viii }}$ As his colleagues abandon the wait and leave, the engineer crosses into a kind of limbo. Time passes, but the point at which he can start work recedes ever further, and he becomes bored to death. Being bored to death is distinct from 'becoming bored by' or 'being bored with'. It transcends both the frustration of the former and the joylessness of the latter, instead approaching Heidegger's third form of boredom: 'Profound Boredom' (Heidegger 1995, 132).

'Profound Boredom' is the kind of boredom that Kracauer aspires towards in his article. It involves reconciling ourselves to, and even embracing, the emptiness that exists within and beyond the limited time of our lives. Being bored to death is not a morbid attitude, however. In fact, it is profoundly ethical. It involves an appreciation of the fact that time is not under our control, and that we cannot actually 'kill time' at all. Time passes, we die, and time continues to pass. Appreciating this fact makes us better equipped to appreciate the various temporalities that exist beyond our own. It allows us to appreciate, as Heidegger puts it, that 'each thing, as we say, has its time (Heidegger 1995, 105). After a while, the engineer adapts to village life and stops asking about the progress of the old woman. Being bored to death does not, however, preclude taking action to save life. Towards the end of The Wind Will Carry Us, an accident suddenly motivates the engineer into action. A villager becomes trapped in a hole on the hill where the engineer receives his phone calls. When faced with the possibility 
of the villager's untimely death, the engineer drives at high speed back down the hill, finds a group of villagers, and lets them know about the accident. Following a brief sequence in which he seems not to realise that his jeep is the only means by which a rescue mission can take place, he lends it to some villagers, who race up the hill to save the man. As the film's sole narrative vehicle drives off into the distance, the engineer returns to village time. He talks to the doctor who treated the injured man, and persuades him to look in on the old woman.

The Wind Will Carry Us neither entertains nor leaves a feeling of emptiness afterwards. Indeed, by allowing us to watch the engineer learn to give the villagers the time they deserve, and by playing out Kiarostami's own attunement to the temporality of his non-professional actors (as demonstrated, for example, by his use of long takes), the film allows us also to attune ourselves to the villagers' temporality. In doing so, it shows itself, in my view, to be profoundly ethical. Of course, in doing so, the film also risks being called 'boring'. But by failing to give people and things their time, cinema risks far more.

\section{References}

Aronson, Magnus. 2002. Towards a Theory of Borigness. Unpublished article. Heidegger, Martin. 1995. The Fundamental Concepts of Metaphysics: World, Finitude, Solitude. Trans. William McNeill and Nicholas Walker.

Bloomington, Indiana: Indiana University Press.

Kracauer, Siegfried. 1995. Boredom. The Mass Ornament: Weimar Essays.

Trans. Thomas Y. Levin. Cambridge, MA and London: Harvard University Press: 331-334.

Svendsen, Lars. 2005. A Philosophy of Boredom. London: Reaktion.

Wajda, Andrzej. 1989. Double Vision: My Life in Film. London and Boston: Faber and Faber. 
i This assertion, in a sense, is the inverse of the dreaded parental reproach that there are no boring things just boring people, which implies that by finds an object boring, the child is in fact demonstrating not the object's boringness but her or his own propensity towards boredom, and thus her or his own boringness. By contrast, the above assertion posits that there are no boring things, and no boring people either, just boredom.

ii Heidegger refers to 'becoming bored by' as 'The First Form of Boredom' (Heidegger 1995, 78). He refers to 'being bored with' as 'The Second Form of Boredom' (Heidegger 1995, 106). There is also a third form of boredom, which Heidegger labels 'Profound Boredom' (Heidegger 1995, 132). This is a more essential form of boredom, which transcends time (Heidegger 1995, 144). Because it exists separately from time, this form of boredom does not have a privileged relationship with cinema, and so I do not discuss it in detail.

iii Clearly, in the context of domestic viewing, when playback time is controllable by the viewer, there is an extra variable at work. The potential for an individual film or television show to bore is diminished, though there still remains potential for 'becoming bored by' and 'being bored with' the overall experience of watching television all evening.

${ }^{\text {iv }}$ Kracauer also refers to killing time, though he does so without reference to film (Kracauer 1995, 93).

${ }^{v}$ Conversely, entertainment occurs when there is a fit between the speed at which a film moves and the speed at which we want it to move. Most screenwriters and directors aspire towards achieving such a fit. Screenwriting 'how-to' manuals are essentially instruments for structuring the way in which a film 'passes time', and for reconciling the speed of films' narratives with viewers' expectations.

${ }^{\mathrm{vi}}$ The association between slowness and boredom raises some seemingly paradoxical questions. For example: 'We pass the time, in order to master it, because time becomes long in boredom. Time becomes long for us. Is it supposed to be short, then? Does not each of us wish for a truly long time for ourselves? And whenever it does become long for us, we pass the time and ward off its becoming long!' (Heidegger 1995, 80). In fact, this not quite the paradox it seems to be. As Magnus Aronson notes, the same phenomena may trigger boredom in some contexts and not others. In some contexts, for example, slowness, repetition, and lack of information may bore; in others, they may give pleasure, for example: 'slowness in the sexual act, repetition in music, lack of information in a minimalist interior and lack of events during a boat trip down a beautiful river' (2002).

vii Our expectations of the speed at which films should move has also increased: we watch films more intelligently than before, we make connections quicker, cover narrative ground faster, and typically expect films to do the same. As a result, there is much more opportunity than ever before for films to drag, and for us to become bored by them.

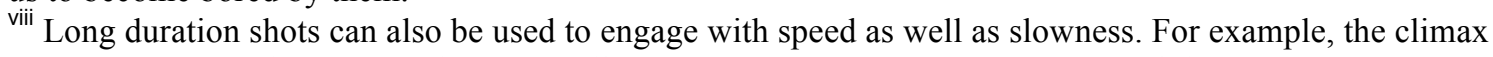
of Atanarjuat (Zacharias Kunuk, 2001) follows an Inuit runner sprinting for many kilometres, trying to outrun a lynch mob. The sequence lasts a long time both in the film's diegetic time and in its running time. Its long duration shots allow us to appreciate the runner's astonishing stamina in a way that the fast cutting of a typical action movie could not. 